\title{
Problem-, Project- and Design-Based Learning: Their Relationship to Teaching Science, Technology and Engineering in Schooll
}

\author{
Moshe Barak \\ Department of Science and Technology Education, Ben-Gurion University of the Negev Beer Sheva, Israel
}

Purpose: The present study aims at shedding light on the meaning of three teaching and learning methods - problem-based learning, project-based learning and design-based learning, aimed at fostering students' lifelong learning skills such as problem solving, collaborative learning and self-direct learning.

Methods: This work is derived from the literature of constructivist pedagogy, and student-centered teaching and learning methods with focus on science, technology and engineering.

Results: Problem-based learning has to do mainly with creating theoretical knowledge, for example in science or mathematics. In project-based learning, there is a longstanding tradition in schools for "doing projects," incorporating "hands-on" activities, developing interdisciplinary themes, implementing laboratory investigations and the creation of a useful artifact or system. Design-based learning corresponds to project-based learning, except that DBL requires learners to work according to acceptable engineering design processes. In the hearth of engineering design is generating alternative solutions and choosing systematically the optimal one, because engineering is merely a process of optimization and tradeoff.

Conclusions: In the present article, we have highlighted the differences between three problem-based learning, project-based learning and design-based learning, with hope that becoming familiar with these teaching methods will encourage educators and engineers to integrate them into teaching science, technology and engineering in schools.

Keywords: Constructivist pedagogy; Problem-based learning; Project-based learning and design-based learning

\section{INTRODUCTION}

The rapid scientific, technological and social changes and the digital revolution in particular, have been altering almost every aspect of life, for example, the ways people work, shop, communicate, travel and spend their leisure time. To prepare students to integrate into the modern world and work place, schools are required to impart to students not only knowledge in science, technology, engineering and mathematics (STEM), and computing, but also lifelong learning skills. This includes the ability to solve problems, work both independently and on a team, communicate effectively in different formats, and self-direct one's learning (OECD, 2018). To reach these goals, education must move from the conservative lecture-based teaching method to constructivist learner-centered instructional methods such as problem-based learning, project-based learning and design-based learning, which are derived from seminal philosophers and educators such as Jean Piaget (1896-1980), John Dewey (1859-1952) and Seymour Papert (1928-2016). However, the three terms mentioned above are somewhat am-

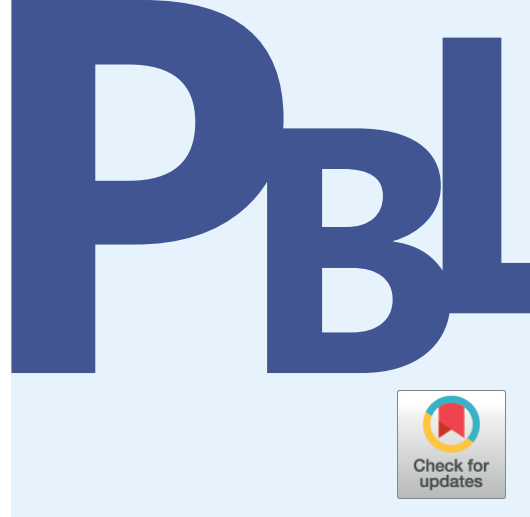

Review Article

pISSN 2288-8675 · elSSN 2508-9145

J Probl Based Learn 2020;7(2):94-97

https://doi.org/10.24313/jpbl.2020.00227

Received: April 16, 2020

Revised: July 4, 2020

Accepted: July 13, 2020

Corresponding author:

Moshe Barak,

Department of Science and

Technology Education Ben-Gurion

University of the Negev P.0.B. 653

Beer-Sheva 8410501 Israel

Tel: +972-507922575

Fax: +972-48704431

E-mail:mbarak@bgu.ac.il
(C) Copyright 2020 International Society for Problem-Based Learning

(c) This is an Open Access article distributed under the terms of the Creative Commons Attribution Non-Commercial License (http://creativecommons.org/licenses/ by-nc/4.0/) which permits unrestricted non-commercial use, distribution, and reproduction in any medium, provided the original work is properly cited. 
biguous, and the difference between them is unclear. The purpose of this article is to shed light on the meaning of the terms problem-, project- and design-based learning within the context of teaching science, technology and engineering in school.

\section{PROBLEM-BASED LEARNING (PBL)}

Problem-based learning is a student-centered pedagogy in which students learn about a subject through the experience of solving an open-ended problem found in the literature. The PBL process does not focus on problem solving with a defined solution, but it allows for the development of other desirable skills and attributes such as knowledge acquisition, enhanced group collaboration and communication.

Problem-based learning is often described as including the following steps:

1. Explore the issue

2. State what is known

3. Define the issues

4. Research the knowledge

5. Investigate solutions

6. Present and support the chosen solution

7. Review your performance.

Problem-based learning was originally developed within the context of medicine studies, but the use of PBL has expanded to include education in areas such as science math, computer sciences law, economics, business and social studies (Barrow, 1996; Hmelo-Silver, 2004; Kim, 2019; Savery \& Duffy, 1995). From the perspective of STEM education, problem-based learning has to do mainly with creating knowledge, for example in science or mathematics, or computer sciences, in which the problem and the solution could be on the theoretical level only.

\section{PROJECT-BASED LEARNING (PjBL)}

Project-based learning (sometimes also called PBL) is a model that organizes learning around complex tasks based on challenging questions or problems that involve students in design, problem-solving, decision-making, or investigative activities (Thomas, 2000). In project-based learning, there is a longstanding tradition in schools for "doing projects," incorporating "hands-on" activities, developing interdisciplinary themes, implementing laboratory investigations and the creation of a useful artifact or system (Barak \& Zadok, 2009; Blumenfeld et al., 1991; Vargas, Ortiz, Pueyo, \& Rodríguez, 2019). Project-based learning is often described as comprising five main stages: identifying a problem or need; investigating; planning a technological device; construction and trou- bleshooting; and evaluating, as illustrated in Figure 1.

Students' projects could include, for example, a robotics or automatic irrigation system. It is important to note that project-based learning is a cyclical and not a linear process. Moreover, this is an iterative process in which a developer can jump back or forth from one stage to another.

\section{DESIGN-BASED LEARNING (DBL)}

The term design is associated with engineering. Design-based learning is similar to project-based learning, except that DBL requires learners to work according to acceptable engineering design processes.

Burghardt and Hacker (2004) suggested the term 'informed design cycle' including the following eight stages:

1. Clarifying design specifications and constraints

Describing the problem clearly and fully, noting constraints and specifications.

2. Researching and investigating the problem

Searching for and discussing solutions to solve this or similar problems. Completing a series of guided-knowledge and skill-builder activities that will help students identify the variables that affect the performance of the design, and inform the students' knowledge and skill base.

\section{Generating alternative designs}

Not stopping when we have one solution. Approaching the challenge in new ways and describing alternatives.

4. Choosing and justifying the optimal design

Rating and ranking the alternatives against the design specifications and constraints. Justifying a choice that will guide the preliminary design.

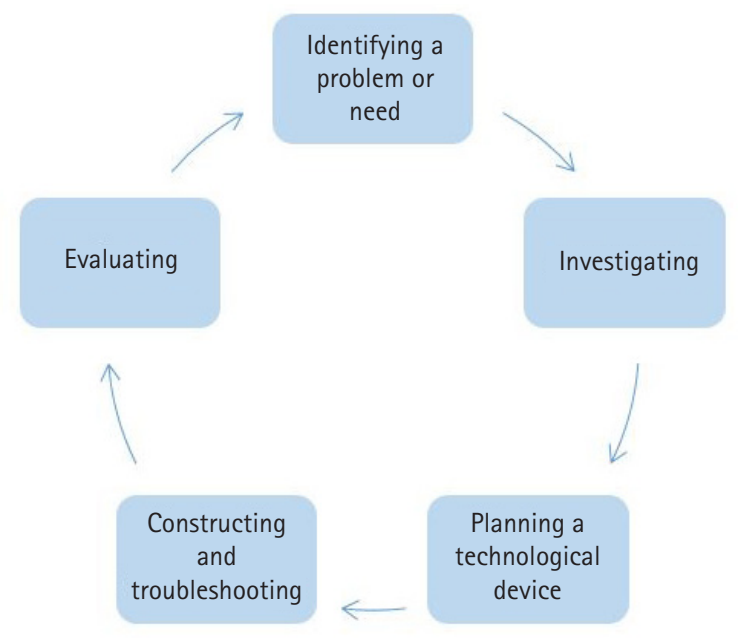

Figure 1. Project-based learning process. 


\section{Developing a prototype}

Making a model of the solution. Identifying and explaining modifications to refine the design.

6. Testing and evaluating the design solution

Developing and carrying out a test to assess the performance of the design solution.

7. Redesigning the solution with modifications

Examining the design compared to other solutions to see where improvements can be made. Identifying the variables that affect performance and determining the concepts that underlie these variables. Explaining how to enhance the performance of the design using these concepts and variables.

8. Communicating the achievements.

Completing a design portfolio or design report that documents the previously mentioned steps. Making a group presentation to the class justifying the design solution.

In this case, too, we must note that the design work is an iterative cycle in which a designer can move back or forth from one stage to another; it is not a linear process.

Stages 3 and 4, Generate alternative designs and Choose and justify the optimal design, are central to the engineering design because engineering is merely a process of optimization and tradeoff. Designers often cannot develop a product or system that fully meets all requirements, for example, in terms of performance, ease of use, reliability, safety, or cost. They develop several solutions and systematically check for the optimal one, for example, by preparing a performance scale for choosing the optimal solution. These steps, which are at the heart of design-based learning, are less central to the general model of project-based learning mentioned above. In fact, DBL differs from PjBL mainly in this aspect.

\section{Students' activities in problem-, project- and design-based learning}

Problem-, project- and design-based learning are forms of constructivist pedagogy derived from the constructivism theory that individuals create their own new understandings based on an interaction between what they already know and knowledge with which they come into contact. Constructivism also stresses that learning is a social activity, something people do together in interaction with each other, rather than an abstract concept (Dewey, 1938; Vygotsky, 1978; Resnick, 1989). The type of learner's activity, which is at the heart of problem-, project- or designbased learning, is slightly different in each of the three models. In problem-based learning, students' activities could include, for example, identifying a problem in the intermediary environment, collecting data from the field by observations and interviews, carrying out a literature survey, formulating a solution, writing the research report and presenting it to others. In project- and design-based learning, students also conduct investigations, but the heart of their activity is the design and construction of an artifact or system that is personally meaningful to them, could be shared with others and reflected upon (Thomas, Mergendoller, \& Michaelson 1999; Harel \& Papert, 1991). Project-based learning is common in areas such as electronics and computer science, which emphasize the development of rich and innovative systems. Design-based learning is common in areas such as mechanical or construction engineering, which also require addressing design standards, such as the optimal use of materials and energy or coping with safety issues. Knoll (1997) shows that the beginnings of project work started within vocational education in the years 1590-1765 in architectural schools in Europe. Later, and until today, the project method became a regular teaching scheme in universities and schools worldwide, with adaptation to specific disciplines. Students prepare a project within the requirements of particular courses or as a final work at the end of school.

\section{Teacher's role in the constructivist class}

Despite wide consensus in the literature about the advantages of student-centered pedagogy over traditional schooling, educators are increasingly aware of the limitations of applying these methods within the regular school context. Kirschner, Sweller and Clark (2006) write about the failure of constructivist-oriented instructional methods such as discovery, problem-based and inquiry-based learning because the notion of minimal guidance during learning does not work for novice learners. Instructional approaches that place strong emphasis on guiding the students' learning process are more effective in the first stages of learning a new subject. Some supporters of PBL (Hmelo-Silver, 2004; Hmelo-Silver, Duncan, \& Chinn., 2007; Savery, 2006) mention that it is important to tailor the scope and complexity level of assignments to students' prior knowledge and skills, and provide instruction and support in order to reduce the cognitive load and enable students to learn in a complex domain. For the implementation of $\mathrm{PjBL}$ and $\mathrm{DBL}$ in engineering, the teacher is also required to prepare the technical infrastructure for students' work, for example, computers, tools, materials and measuring devices for the construction of electronic or mechanical systems.

\section{CONCLUSIONS}

Many countries worldwide place great importance on teaching science, technology and engineering in the educational system, from kindergarten to high school. In this article, we have ad- 
dressed three educational approaches, problem-based learning $(\mathrm{PBL})$, project-based learning $(\mathrm{PjBL})$ and design-based learning (DBL, which may be suitable for teaching science, technology and engineering for children. We hope that becoming familiar with these teaching methods will encourage educators to integrate them into teaching science, technology and engineering in schools.

\section{REFERENCES}

Barak, M., \& Zadok, Y. (2009). Robotics projects and learning concepts in science, technology and problem solving. International Journal of Technology and Design Education, 19(3), 289-307.

Barrow, H. S. (1996). Problem-based learning in medicine and beyond: a brief overview. New Directions for Teaching and Learning, 68, 3-12.

Blumenfeld, P. C., Soloway, E., Marx, R. W., Krajcik, J. S., Guzdial, M., \& Palincsar, A. (1991). Motivating project-based learning: sustaining the doing, supporting the learnin. Educational Psychologist, 26(3-4), 369-398.

Burghardt, M. D., \& Hacker, M. (2004). Informed design: a contemporary approach to design pedagogy as the core process in technology. Technology Teacher, 64(1), 6-8.

Dewey, J. (1938). Experience and Education. New York: Collier Books.

Harel, I., \& Papert, S. (Eds.). (1991). Constructionism. Norwood, NJ: Ablex.

Hmelo-Silver, C. E. (2004). Problem-based learning: what and how do students learn? Educational Psychology Review, 16(3), 235-266. https://dandtfordandt.wordpress.com/2016/09/11/ dt-for-the-next-generation.

Hmelo-Silver, C. E., Duncan, R. G., \& Chinn, C. A. (2007). Scaffolding and achievement in problem-based and inquiry learning: a response to Kirschner, Sweller, and Clark (2006). Educational Psychologist, 42(2), 99-107. https://doi.org/10.1080/0046 1520701263368.
Kim, G. H. (2019). A Learning Model for Software Coding Education. Journal of Problem-Based Learning, 6(2), 67-75. https:// doi.org/10.24313/jpbl.2019.00164.

Kirschner, P. A., Sweller, J., \& Clark, R. E. (2006). Why minimal guidance during instruction does not work: an analysis of the failure of constructivist, discovery, problem-based, experiential, and inquiry based teaching. Educational Psychologist, 41(2), $75-86$.

Knoll, M. (1997). The project method: Its vocational education origin and international development. Journal of Industrial Teacher Education, 34(3), 59-80.

Organization for Economic Co-operation and Development (OECD) (2018). The Future of Education and Skills Education 2030. https://www.oecd.org/education/2030/E2030\%20Position\%20Paper\%20(05.04.2018).pdf.

Resnick, L. B. Introduction. In L. B. Resnick (Ed.), Knowing, Learning, and Instruction: Essays in Honor of Robert Glaser. (pp. 1-24). Hillsdale, NJ: Erlbaum.

Savery, J. R. (2006). Overview of problem-based learning: definitions and distinctions. Interdisciplinary Journal of Problem-Based Learning, 1(1), 9-20.

Savery, J. R., \& Duffy, T. M. (1995). Problem-based learning: an instructional model and its constructivist framework. Educational Technology, 35(5), 31-38.

Thomas, J. W. (2000). A review of research on project-based learning. San Rafael California, The Autodesk Foundation.

Thomas, J. W., Mergendoller, J. R., \& Michaelson, A. (1999). Project-based Learning Handbook for Middle and High School Teachers. Novato CA, Buck Institute for Education. .

Vargas, N. V., Ortiz, J. L. A., Pueyo, N. P., \& Rodríguez, A. R. L. (2019). Project-based learning to enhance environmental education through automobile mechanics. Journal of Problem-Based Learning, 6(2), 76-84.

Vygotsky, L. S. (1978). Mind In Society: The Development Of Higher Psychological Processes. Cambridge, MA: Harvard University Press. 
